\title{
EVALUATION OF THE EFFICIENCY OF AN NOISE BARRIER ALONG THE RAILWAY LINE RZESZOW-MEDYKA
}

\begin{abstract}
The noise is generated by trains due to the operation of the engine, the wheels rolling on rails and train aerodynamics. In order to reduce rail noise one can distinguish passive and active measures aimed at reducing noise. The passive noise protection measures include railway noise barriers and insulated windows. In this article the efficiency of noise barriers along the railway line Kraków - Medyka in Debica has been discussed. The test screen with a length of about $590 \mathrm{~m}$ and a height of $3 \mathrm{~m}$ located on the embankment height of $4 \mathrm{~m}$ protects singlefamily housing residents against excessive influence of railway noise. The efficiency of the test screen depending on the type of the train and the track it is moving on is in the range between $4-17 \mathrm{~dB}$.
\end{abstract}

Keywords: noise barrier, efficiency, railway line, rail noise

\section{Introduction}

According to Directorate-General Internal Policies twelve mln residents of the UE are exposed to noise generated by trains, above $55 \mathrm{~dB}$ level during the day and nine mln is exposed to noise above $50 \mathrm{~dB}$ at night. It should be added that the listed values of the EU population exposed to noise are higher, because the initiative of the European Environment Agency concerns agglomerations of more than 250000 inhabitants and the main railway line, which runs more than 60000 trains per year [9]. The noise is a harmful phenomenon which causes noise pollution and negatively affects people exposed to it [4]. The noise is generated by trains due to the operation of the engine, the wheels rolling

${ }^{1}$ Author for correspondence: Karol Pereta, Politechnika Rzeszowska, Poznańska 2, 35-084 Rzeszów, +48 17 8651618, kpereta@prz.edu.pl.

${ }^{2}$ Leonard Ziemiański, Politechnika Rzeszowska, Poznańska 2, 35-084 Rzeszów, +48 17 8651353, ziele@prz.edu.pl. 
on rails and train aerodynamics[3]. In order to determine the acoustic climate in the near of railways performed researches about $\mathrm{L}_{\mathrm{AeqD}}$ and $\mathrm{L}_{\mathrm{AeqN}}$. Such researches are described in [2]. Sound level $\mathrm{L}_{\mathrm{AeqD}}$ and $\mathrm{L}_{\mathrm{aeqN}}$ can be calculated by acoustic map. Acoustic maps are also used to predict the noise. The obligation to establish noise maps in Poland, it was introduced in [11]. The process of creating noise maps and their analysis are discussed in [1]. By welldon acoustic map we can select a good noise barriers and their locations. In [5] shows the noise barriers used along railways in Germany (screens with small height) and in France. Examples noise barriers with small height have ben shown in [6].

In order to reduce rail noise one can distinguish passive and active measures aimed at reducing noise[10]. The passive noise protection measures include railway noise barriers and insulated windows. The aim of the paper is the efficiency of noise barriers along the railway line Kraków - Medyka in Debica has been discussed.

\section{Description of the test screen}

An absorbing screen has been studied. The length of the screen is equal to $590 \mathrm{~m}$ and the height is equal to $4 \mathrm{~m}$. The screen under discussion is located along the railway line Rzeszow - Medyka. The tracks are located on the embankment and have a height of $4 \mathrm{~m}$. Single-family houses are protected by absorbing noise barriers. The screen which is located on the viaduct is a reflective screen.

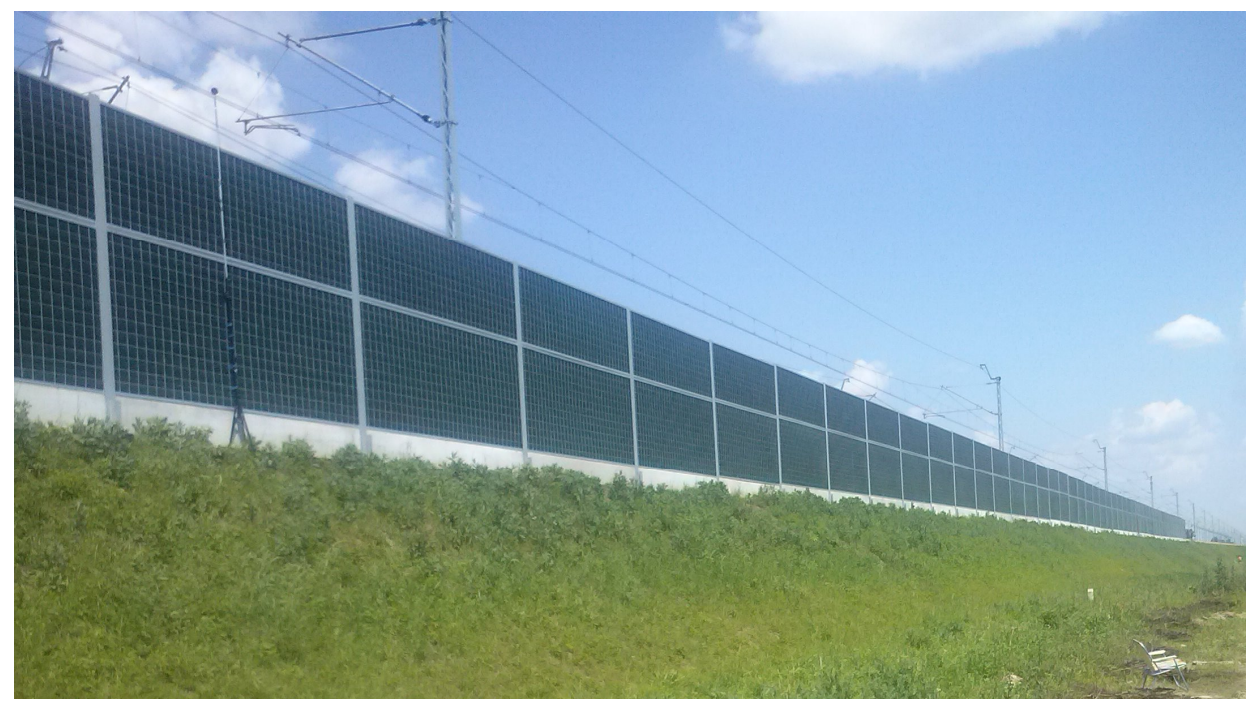

Fig. 1. Noise barrier view (in the direction of Rzeszow)

Rys. 1. Widok bariery akustycznej (w kierunku Rzeszowa) 


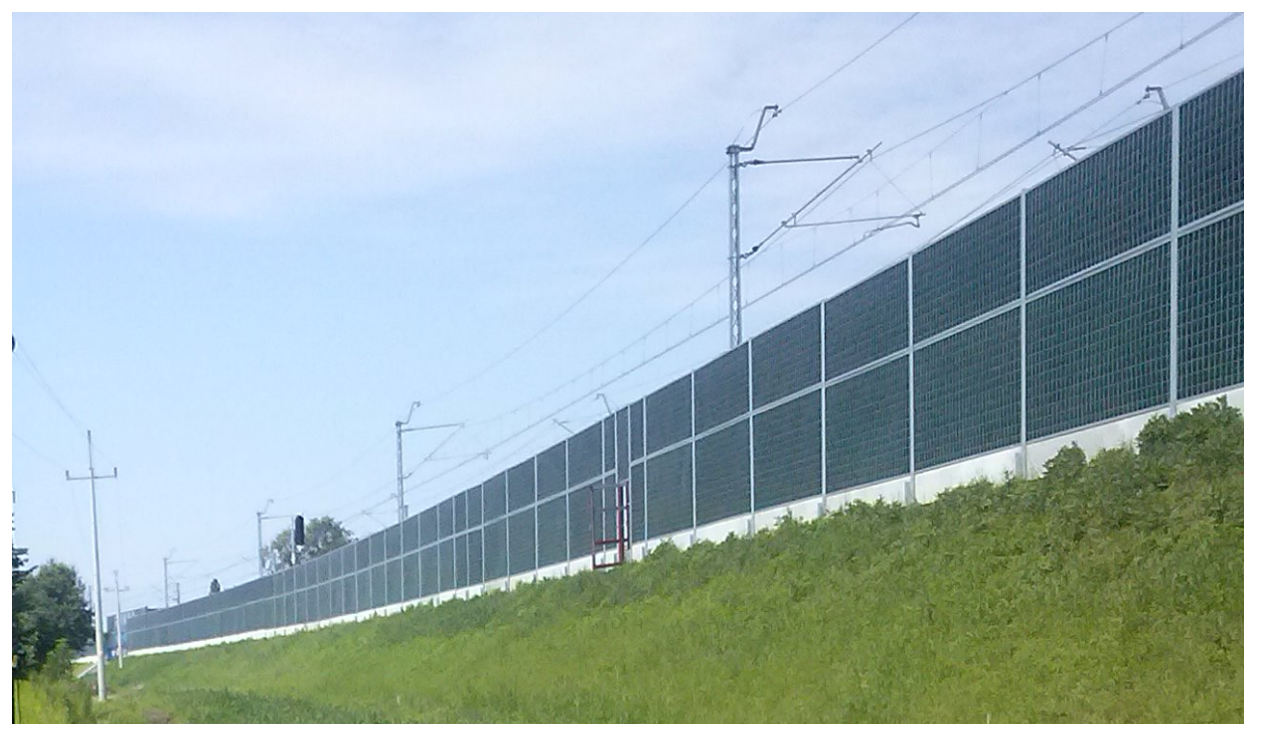

Fig. 2. Noise barrier view (in the direction of Dębica)

Rys. 2. Widok bariery akustycznej (w kierunku Dębicy)

\section{Experimental evaluation of the screen efficiency}

The evaluation of the efficiency has been made by indirect method in accordance with [7] and the requirements specified in [8]. Estimated sound pressure level „before" installing the screen was designated in a place which is the equivalent of the research space. This area has been chosen in accordance with the guidelines given in [7].

\subsection{Measuring apparatus}

Equipment Brüel \& Kjær has been used for acoustic testing: two-channel, manual meter type 2270, microphones types 4189 with guards against winds AU-0237, AU-1650 and microphone stands (Fig. 3). The weather conditions have been measured by weather station HOBO U30-NRC equipped with anemometer, hygrometer, thermometer and recorder.

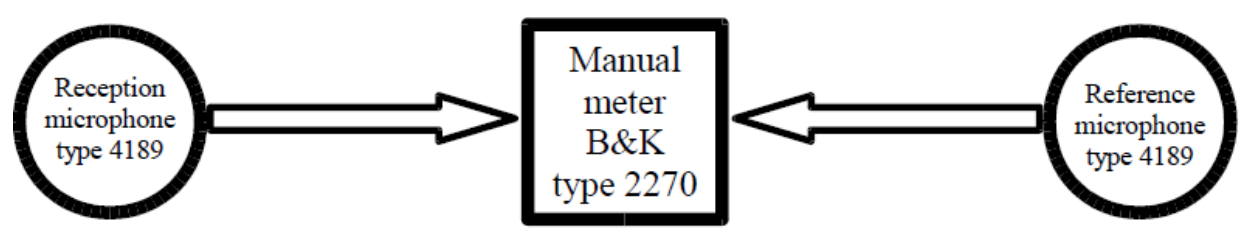

Fig. 3. Reception microphone, sound level meter B\&K 2270, reference microphone

Rys. 3. Mikrofon odbiorczy, miernik poziomu dźwięku B\&K 2270, mikrofon odniesienia 


\subsection{Measurement points and schemes}

The Area of study, the location of measurement points and schemes have been shown in Fig. 4.

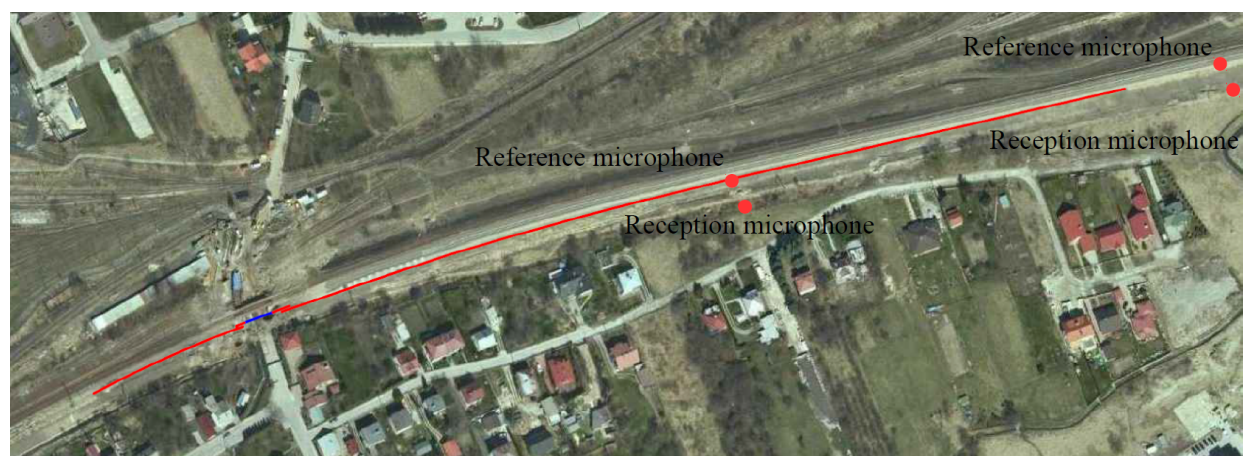

Fig. 4. Area of study

Rys. 4. Obszar badań

Measurements have been carried out in two schemes:

scheme I - measured point has been situated $13 \mathrm{~m}$ away from the screen area and $3 \mathrm{~m}$ above the ground level, reference point has been situated $0.90 \mathrm{~m}$ above the upper screen edge,

scheme II - to determine sound pressure level „before” installing the screen in a place which is equivalent of the research area, location reference point and reception point were the same as in scheme I. This area has been chosen in accordance with the guidelines given in [7].

Position microphones have been presented in Fig. 5

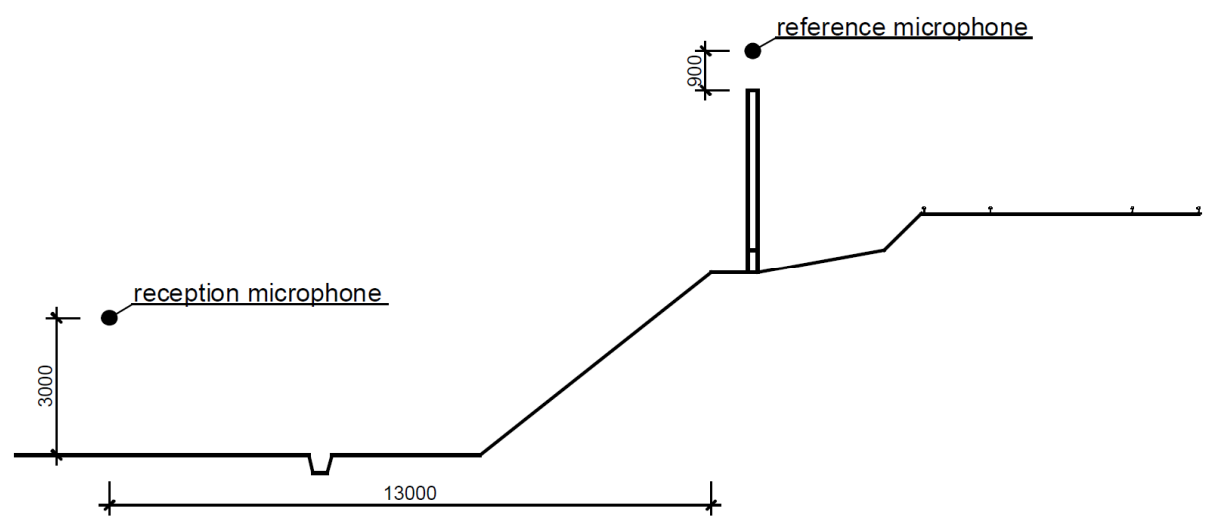

Fig. 5. Arrangement of microphones in both measurement schemes

Rys. 5. Rozmieszczenie mikrofonów w obydwu schematach pomiarów 


\subsection{Results of the measurements}

The maximum temperature which was recorded during the tests was equal to $31^{\circ} \mathrm{C}$ and the minimum was equal to $25^{\circ} \mathrm{C}$. The relative air humidity was within range $37 \%$ to $62 \%$, the wind speed was no more than $2.2 \mathrm{~m} / \mathrm{s}$. At $1 / 3$ octave bands the sound pressure level was being recorded. The characteristic correction "A" was used. Sound pressure at reference and reception points was being synchronised. Examples of noise spectrum at reference and reception points have been shown in Fig. 6. The measured background noise level was lower by about $15 \mathrm{~dB}$ of registered train traffic. According to [7] in this case the impact of background noise has been omitted.

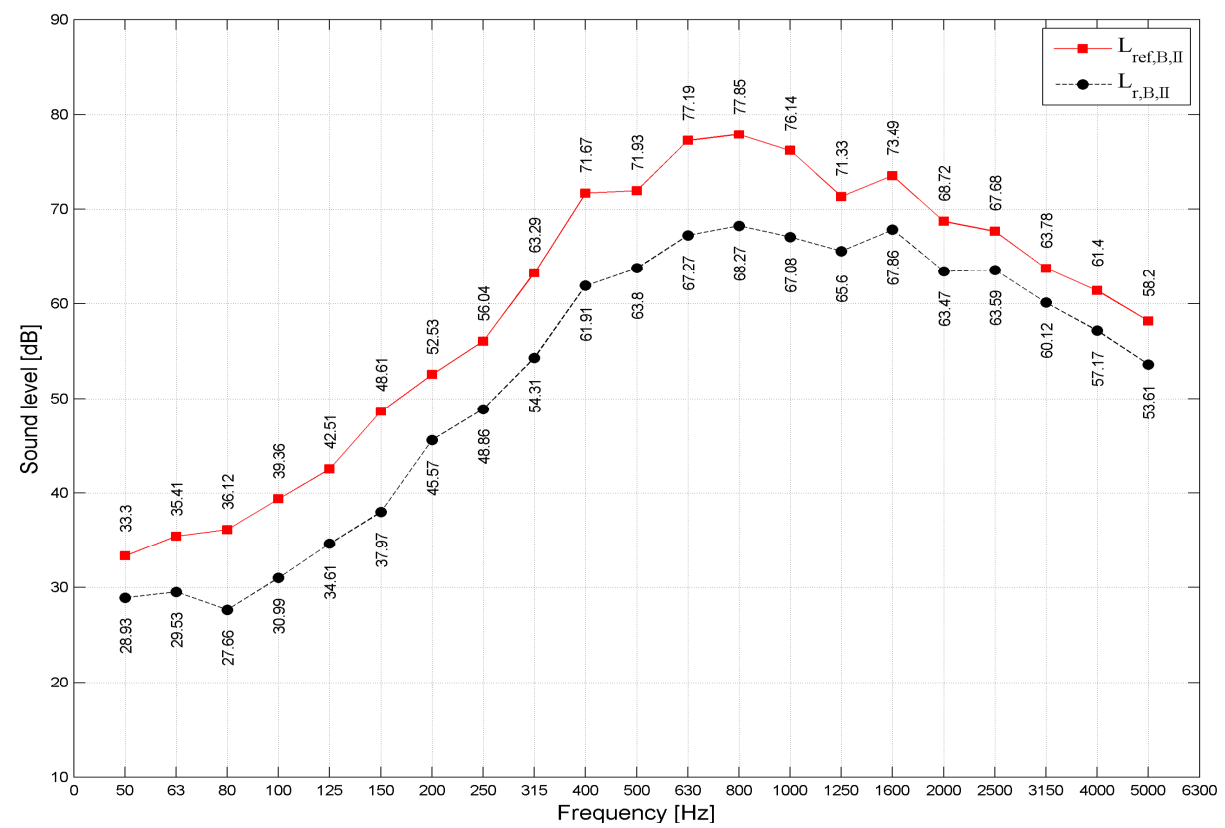

Fig. 6. Sound spectrum at the reference and reception point in comparative area for $2^{\text {nd }}$ train Rys. 6. Widmo akustyczne w punktach odbiorczym i odniesienia w porównaniu dla 2-go pociągu

Recorded in the 1/3-octave bands sound levels have been converted to equivalent sound levels with the use of formula (1)[12]:

$$
L_{j}=10 \log \left(\sum_{i=1}^{21} 10^{0.1 L_{i, j}}\right)
$$

where: $L_{i}$ - equivalent sound level

$L_{i, j}$ - sound level in 1/3-octave band sound for the event. 
The values of equivalent sound levels at individual measurement points for the individual measurements have been shown in Table 1.

Table 1. Equivalent sound levels on $[\mathrm{dB}]$ for each measurement scheme

Tabela 1. Równoważnik poziomów dźwięku [dB] dla każdego schematu pomiarowego

\begin{tabular}{|c|c|c|c|c|c|c|}
\hline \multirow{2}{*}{$\begin{array}{c}\text { Number of } \\
\text { measurement }\end{array}$} & \multirow{2}{*}{$\begin{array}{c}\text { Train } \\
\text { type }\end{array}$} & \multirow{2}{*}{$\begin{array}{c}\text { Track } \\
\text { number }\end{array}$} & \multicolumn{2}{|c|}{ Protected area } & \multicolumn{2}{c|}{ Comparative area } \\
\cline { 4 - 7 } & long-distance & I & 88.36 & 71.59 & 87.52 & 80.36 \\
\hline 1. & local & I & 84.82 & 61.18 & 83.82 & 75.74 \\
\hline 2. & goods & I & 76.39 & 63.51 & 81.00 & 77.19 \\
\hline 3. & long-distance & II & 82.04 & 57.54 & 84.95 & 66.40 \\
\hline 4. & local & II & 78.80 & 54.78 & 80.45 & 60.88 \\
\hline 5. & long-distance & II & 79.63 & 55.27 & 85.71 & 66.75 \\
\hline 6. & local & II & 73.23 & 50.19 & 79.11 & 60.64 \\
\hline 7. & local & I & 73.15 & 50.18 & 82.13 & 74.41 \\
\hline 8. & & I & 88.64 & 64.18 & 88.23 & 80.84 \\
\hline 9. & long-distance & & & & & \\
\hline
\end{tabular}

Differences between sound levels at the reference point and the reception point have been calculated and the results have been shown in Table 2 .

Table 2. Efficiency of an noise barrier

Tabela 2. Skuteczność bariery akustycznej

\begin{tabular}{|c|c|c|c|c|c|}
\hline \multirow{2}{*}{$\begin{array}{c}\text { Number of } \\
\text { measurement }\end{array}$} & \multirow{2}{*}{$\begin{array}{c}\text { Train } \\
\text { type }\end{array}$} & \multirow{2}{*}{$\begin{array}{c}\text { Track } \\
\text { number }\end{array}$} & \multicolumn{2}{|c|}{ Sound level difference } & Acoustic efficiency \\
\cline { 4 - 5 } & & $\Delta \mathrm{L}_{\mathrm{A}}[\mathrm{dB}]$ & $\Delta \mathrm{L}_{\mathrm{B}}[\mathrm{dB}]$ & $\left(\mathrm{D}_{\text {IL }}\right)[\mathrm{dB}]$ \\
\hline 1. & long-distance & I & 16.77 & 7.16 & 9.61 \\
\hline 2. & local & I & 23.64 & 8.08 & 15.56 \\
\hline 3. & goods & I & 12.88 & 3.81 & 9.07 \\
\hline 4. & long-distance & II & 24.50 & 18.55 & 5.95 \\
\hline 5. & local & II & 24.02 & 19.57 & 4.45 \\
\hline 6. & long-distance & II & 24.36 & 18.96 & 5.40 \\
\hline 7. & local & II & 23.04 & 18.47 & 4.57 \\
\hline 8. & local & I & 22.97 & 7.72 & 15.25 \\
\hline 9. & long-distance & I & 24.46 & 7.39 & 17.07 \\
\hline
\end{tabular}

Fig. 7 - Fig. 10 present a comparison of the sound spectra of the same type of trains traveling along the same path. 


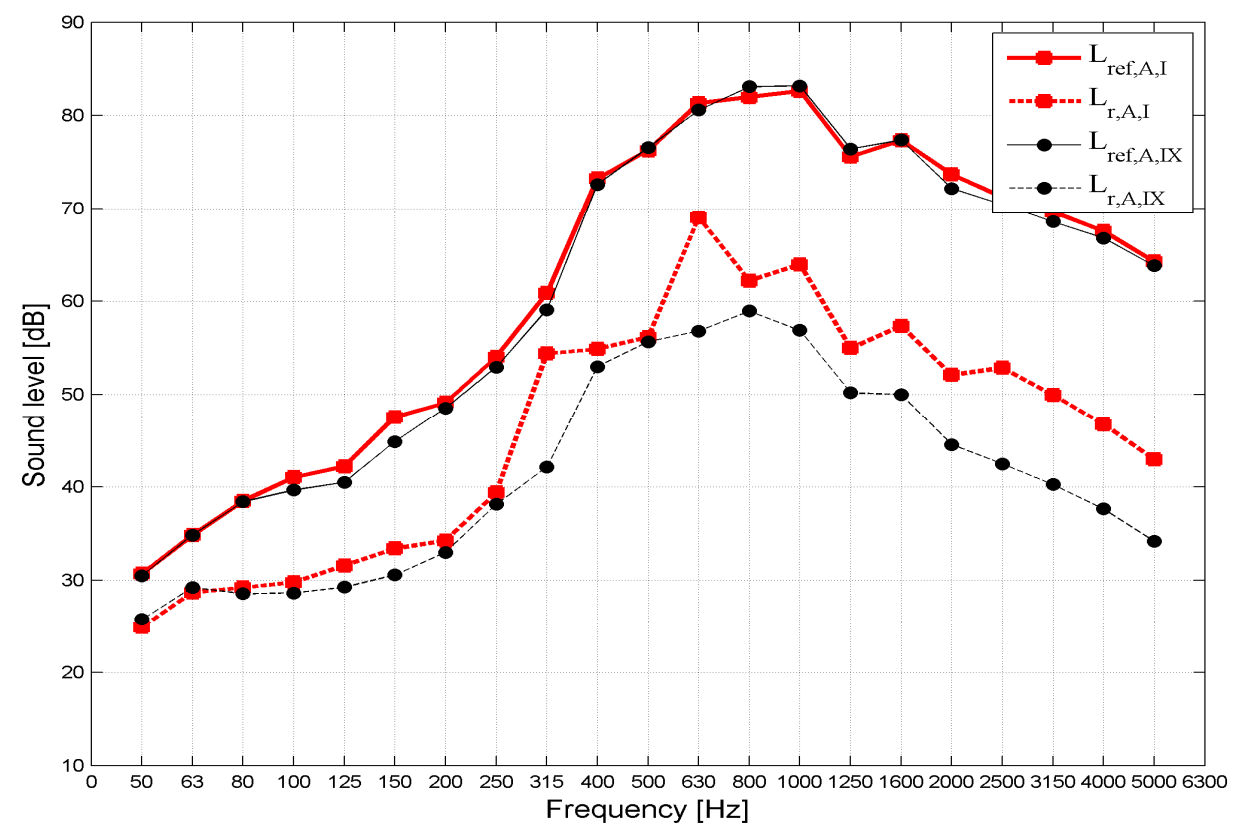

Fig. 7. I and IX measurement on the track I - long distance train Rys. 7. I i IX pomiar na torze I - pociąg dalekobieżny

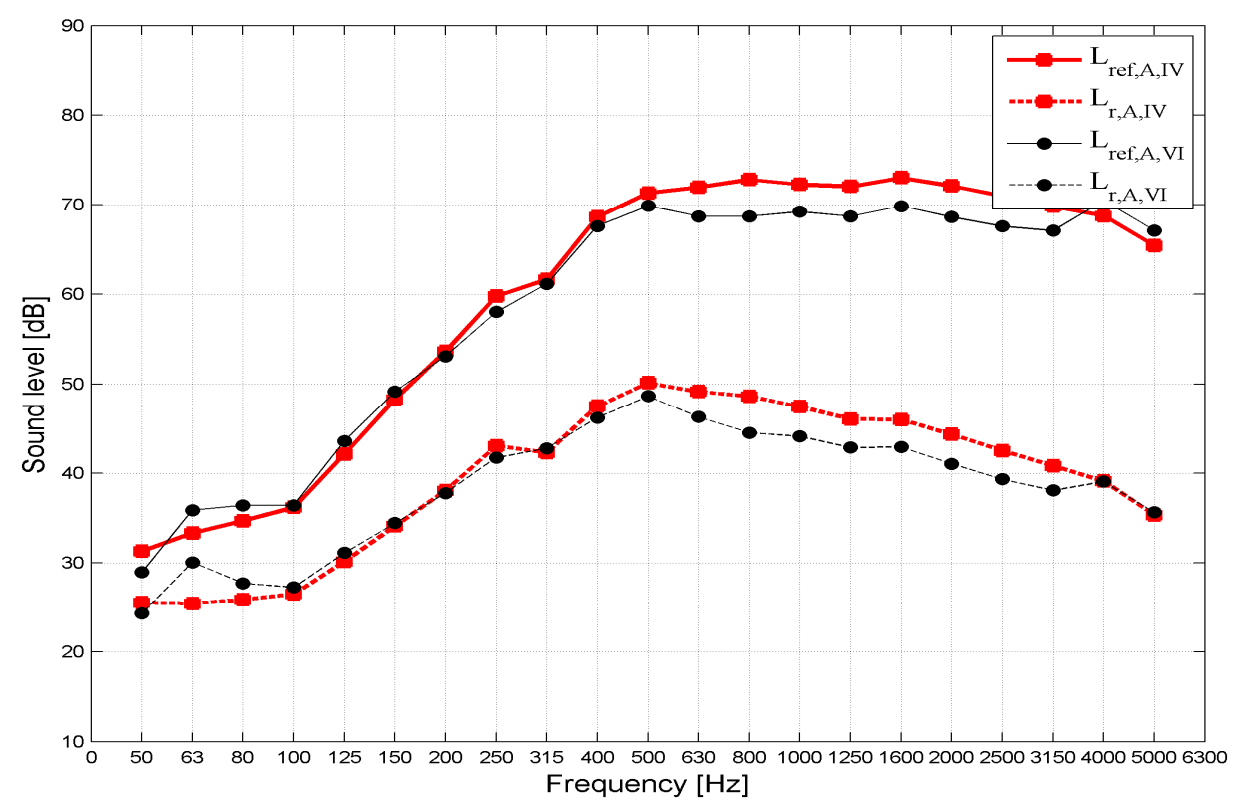

Fig. 8. IV and VI measurement on the track I - long distance train Rys. 8. IV i VI pomiar na torze I - pociąg dalekobieżny 


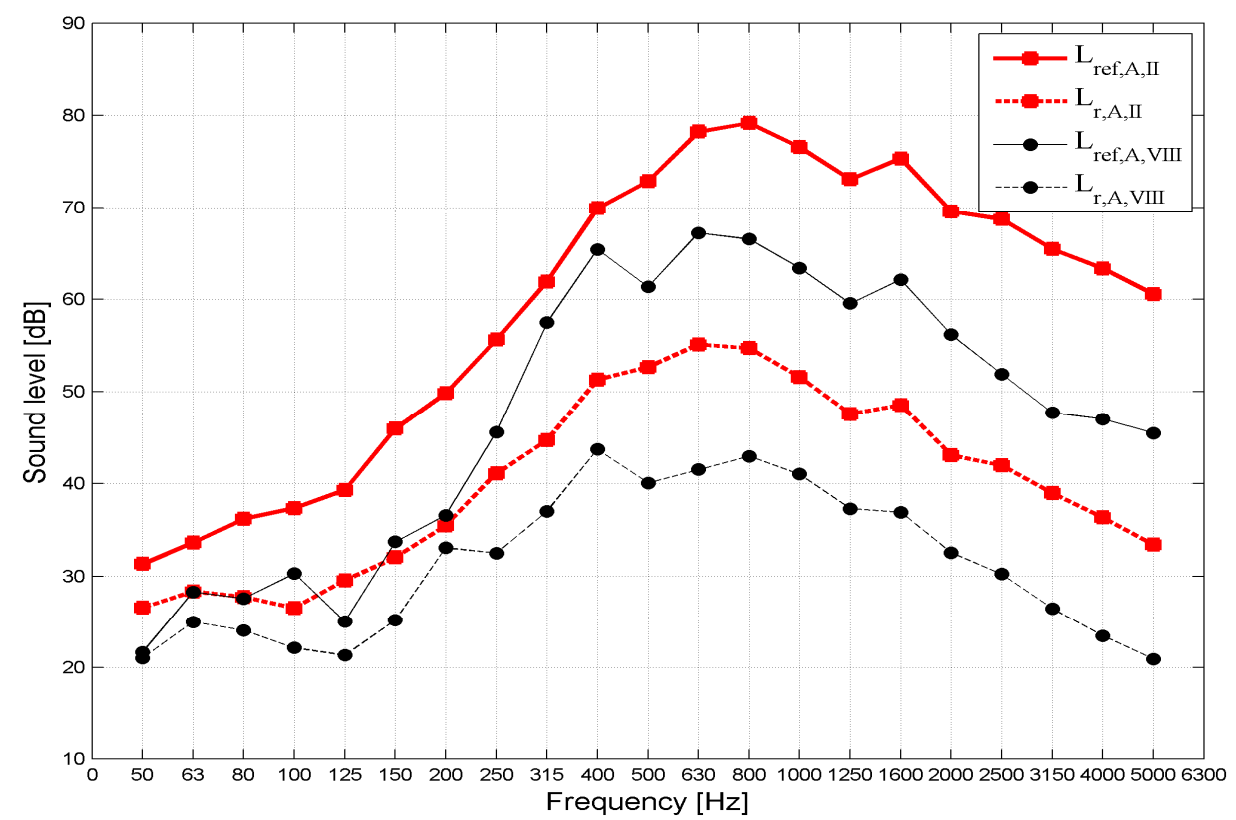

Fig. 9. II and VIII measurement on the track I - local train Rys. 9. II i VIII pomiar na torze I - pociąg lokalny

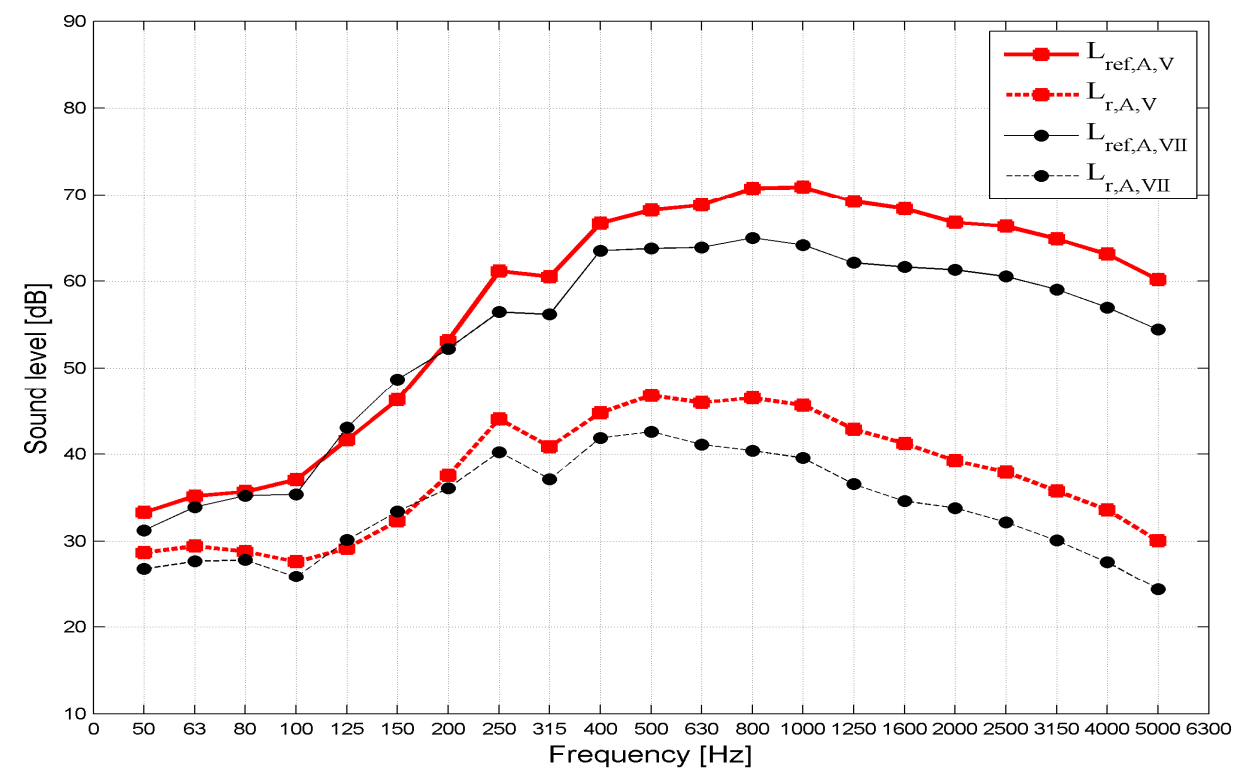

Fig. 10. V and VII measurement on the track I - local train Rys. 10. V i VII pomiar na torze I - pociąg lokalny 


\section{Summary and conclusions}

The efficiency of noise barrier along the railway line Rzeszow - Medyka has been discussed in this paper. The following conclusions have been drawn based on the research:

- the efficiency of the noise barrier for trains going on rails number I for local trains is within range $15 \mathrm{~dB}-16 \mathrm{~dB}$,

- the efficiency of the noise barrier for trains going on rails number II for local and long distance trains is within range $4 \mathrm{~dB}-6 \mathrm{~dB}$,

- the efficiency of the noise barrier for long-distance trains going on the rails I is significantly diffrent. It may result from the disturbances of train no I, such as braking, technical condition or the length of the train,

- the difference between efficiency evaluated for the same type of trains and going along on the same path is lower than $1 \mathrm{~dB}$, the exception is the difference between efficiency for the train I and IX.

Experimentally determined screen efficiency for track II is more important and it determines the efficiency of the noise barrier for a given measurement point location. As expected, the efficiency of the noise barrier calculated for track II is lower than efficiency for track I. Reduced efficiency for track II is due remoteness of the source of the noise barrier which results in:

- reduces the range of acoustic shadow,

- unfavorable change in the angle of deflection of the acoustic wave on the upper edge of the barrier,

- increasing the impact of the phenomenon of curvature of the sound wave to the ground

On the basis of the sound spectra shown in Fig. 7-10 it is clear that the sound spectra for the trains of the same class going on the same path are similar to each other (the exception is the sound spectrum for train I and IX). The difference between individual spectra proves different length and technical conditions of going trains. The results presented in the above paper refer exclusively to a given noise barrier and measurement location. Further research will be carried out in order to allow for precise mapping of the acoustic field behind the presented screen.

\section{Bibliography}

[1] Bohatkiewicz J., Biernacki S., Hałucha M. Analiza wyników map akustycznych opracowanych dla odcinków linii kolejowych o obciążeniu ruchem powyżej 30000 przejazdów rocznie, VIII Seminarium „Wpływ hałasu i drgań wywołanych eksploatacją...” Wibroszyn, Kraków, 2013

[2] Bohatkiewicz J., Biernacki S., Hałucha M. Wariantowanie zabezpieczeń akustycznych dla linii kolejowych w opracowaniach środowiskowych na wybranych przykładach, VIII Se-minarium „Wpływ hałasu i drgań wywołanych eksploatacją...” Wibroszyn, Kraków, 2013 
[3] Czaja P. Ekrany akustyczne a hałas komunikacyjny, http://www.techbud.com.pl/halas1A.htm

[2] Jabben J., Potma C. Sound Exposure Levels from Trains and Sleep Disturbance, Inter-noise 2014, Melbourne, Australia, 16-19 November

[5] Kozłowski W., Surowiecki A. Rozwiązania dotyczące uwarunkowań śodowiskowych w procesie modernizacji magistral kolejowych, Problemy Kolejnictwa Zeszyt 152, str. 251-266.

[6] Morgan P., Peeling J. Railway noise mitigation factsheet 03: Low-height noise barriers, Technical Review, November 2012.

[7] PN-ISO 10847:2002, Akustyka. Wyznaczanie "In Situ" skuteczności zewnętrznych ekranów akustycznych wszystkich rodzajów.

[8] Rozporządzenie Ministra Środowiska z dnia 16 czerwca 2001r. w sprawie wymagań w zakresie prowadzenia pomiarów w środowisku substancji lub energii przez zarządzającego drogą, linią kolejową, linią tramwajową, lotniskiem, portem (Dz. U. $2001 \mathrm{nr} 140$ poz. 824).

[9] Rozporządzenie Ministra Środowiska z dnia 14 grudnia 2006 r. w sprawie dróg, linii kolejowych i lotnisk, których eksploatacja może powodować negatywne oddziaływania akustyczne na znacznych obszarach, dla których jest wymagane sporządzenie map akustycznych, oraz sposobów określania granic terenów objętych tymi mapami (Dz. U. Nr 1, poz. 8).

[10] Tomaszewski F., Wojciechowska E. Transport kolejowy a ochrona środowiska, Wydawnictwo Politechniki Krakowskiej, Kraków 2011

[11] Ustawa z dnia 27 kwietnia 2001 r. - Prawo ochrony środowiska (Dz. U. Nr 25, poz. $150 \mathrm{z}$ późn. zm.).

[12] Zakrzewski T., Żuchowski R. Kompedium akustyki architektonicznej wraz z przykładami metod obliczeniowych. Wydawnictwo Politechniki Śląskiej, Gliwice 2009.

\section{OCENA SKUTECZNOŚCI EKRANU AKUSTYCZNEGO WZDEUŻ LINII KOLEJOWEJ RZESZÓW - MEDYKA}

\section{Streszczenie}

Hałas generowany przez pociągi pochodzi od pracującego silnika, toczących się kół oraz zjawisk aerodynamicznych. W celu ograniczenia hałasu kolejo-wego stosować możemy bierne i czynne środki redukujące hałas. Do zabez-pieczeń pasywnych możemy zaliczyć ekrany akustyczne oraz okna o podwyż-szonym standardzie akustycznym (okna o lepszej izolacyjności akustycznej). W niniejszym artykule omówiono zabezpieczenia przed hałasem kolejowym w postaci ekranów akustycznych. Omawiany ekran zlokalizowany jest wzdłuż linii kolejowej Rzeszów Medyka w miejscowości Dębica. Omawiany ekran o długości około 590m i wysokości 3m znajduje się na nasypie o wyso-kości $4 \mathrm{~m}$. Zadaniem badanego ekranu jest ochrona mieszkańców domów jednorodzinnych przed nadmiernym hałasem kolejowym. Skuteczność bada-nego ekranu $\mathrm{w}$ zależności od rodzaju pociągu i nr toru, po którym się poru-szał mieści się $\mathrm{w}$ przedziale od $4 \mathrm{~dB}$ do $17 \mathrm{~dB}$..

Słowa kluczowe: bariera akustyczna, skuteczność, linia kolejowa, hałas kolejowy

Przesłano do redakcji:26.05.2015

Przyjęto do druku:10.01.2016

DOI: $10.7862 /$ rb.2015.202 